\title{
THE POSITIVE APPROACH TO CHRONIC OSTEOMYELITIS
}

\author{
D. E. Rowling, KirkCaldy, Scotland \\ From the Kirkcaldy General Hospital
}

Chronic osteomyelitis is now probably a curable disease if the surgical attack made upon it is sufficiently radical and is associated with plastic reconstructive methods and antibiotic therapy.

This is a report of fifty-eight cases (Table I). Infection usually originated as an open wound caused by missiles of war, as a compound fracture, or as the blood-borne osteomyelitis of youth. If antibiotics had been given they had not controlled the original infection (Fig. 1). The patients were between seven and sixty-eight years old. The duration of the disease was between one and forty-six years, the discharge having been in some cases constant and in some cases intermittent over that period.

\section{PATHOLOGY}

The extent of the pathological process is underestimated if the condition is regarded only as an infection of bone: many other tissues are affected, including periosteum, muscle, fascia and skin. When sclerosis and fibrosis supervene, strangulation of the small blood vessels causes local tissue anaemia. Thus, even if the correct antibiotic is used, it cannot reach all the infected tissues in sufficient concentration to eradicate the infection. Antibiotic therapy without operation to improve the blood supply cannot cure the disease, and may result in an acquired resistance by the organism. The condition can be cured only if the whole scar, both in the soft tissues and in the bone, is excised and an adequate blood supply carrying the correct antibiotic is constantly delivered to the area. The dead space left by the excision must thus be filled by unscarred living tissue with a good blood supply. Such an operation may be of considerable magnitude because success depends upon the thoroughness of the excision.

\section{TREATMENT}

Indications for operation-Operation is indicated by general debility, by loss of working capacity and social enjoyment, or by persistent pain. Some measure of the disability may be appreciated by the fact that many patients in this series requested amputation, and only two refused operation.

Pre-operative management-When the decision has been made to operate, a deep swab is taken at once from the sinus so that the infecting organisms and their antibiotic sensitivity can be determined. Blood examination and urine analysis are undertaken to exclude chronic nephritis, diabetes or amyloid disease. Anaemia, if present, is corrected and the patient is given a high-protein and high-vitamin diet. A week before admission, and again on the day of admission, the bacteriological investigation is repeated. An antibiotic to which the organisms are most sensitive is selected to cover the operation and the post-operative period without causing toxic effects.

At operation it is sometimes found that pus originating from a different organism lies in the depths of the cavity. If the appearance and odour of the pus are characteristic an additional specific antibiotic can be given during operation, or administered later after laboratory examination of the pus. A bacteriological swab is taken during operation from the deepest part of the sinus. 
TABLE I

Clinical Details of Fifty-eight Patients with Chronic Osteomyelitis

\begin{tabular}{|c|c|c|c|c|c|c|c|c|}
\hline $\begin{array}{c}\text { Case } \\
\text { number }\end{array}$ & $\underset{(\text { years })}{\mathrm{Age}}$ & $\begin{array}{l}\text { Duration } \\
\text { of infection } \\
(\text { years })\end{array}$ & Site & Origin & Tissue replacement & Result & \multicolumn{2}{|c|}{$\begin{array}{l}\text { Follow-up } \\
\text { yearsmonth }\end{array}$} \\
\hline 1 & 32 & 7 & Femur & War wound & Direct closure & $\begin{array}{l}\text { Single brief discharge eighteen } \\
\text { months after operation. } \\
\text { Thereafter healed }\end{array}$ & 7 & 3 \\
\hline 2 & 40 & 24 & Femur & $\begin{array}{c}\text { Acute } \\
\text { osteomyelitis }\end{array}$ & Vastus lateralis & $\begin{array}{l}\text { Eczema persisted nine months. } \\
\text { Thereafter healed. } \\
\text { Primary healing of sinus }\end{array}$ & 6 & 7 \\
\hline 3 & 59 & 36 & Femur & War wound & Vastus lateralis & $\begin{array}{l}\text { Transitory discharge two } \\
\text { months after operation. } \\
\text { Thereafter healed }\end{array}$ & 6 & 0 \\
\hline 4 & 39 & 11 & Femur & War wound & Vastus lateralis & Primary healing & 5 & 11 \\
\hline 5 & 57 & 37 & Femur & War wound & Quadriceps & Primary healing & 5 & 11 \\
\hline 6 & 66 & 36 & $\begin{array}{l}\text { Greater } \\
\text { trochanter }\end{array}$ & War wound & Tensor fasciae latae & $\begin{array}{l}\text { Primary healing. } \\
\text { Scar unstable for one year; } \\
\text { thereafter soundly healed }\end{array}$ & 5 & 10 \\
\hline 7 & 37 & 13 & Femur & War wound & Quadriceps & Primary healing & 5 & 10 \\
\hline 8 & 63 & 38 & Femur & War wound & Vastus lateralis & Primary healing & 5 & 8 \\
\hline 9 & 62 & 37 & Femur & War wound & Direct closure & $\begin{array}{l}\text { Transitory discharge three } \\
\text { months after operation. } \\
\text { Thereafter healed }\end{array}$ & 5 & 6 \\
\hline 10 & 68 & 38 & Femur & War wound & Vastus medialis & $\begin{array}{l}\text { Recurrent decreasing } \\
\text { discharge at yearly intervals }\end{array}$ & 5 & 4 \\
\hline 11 & 43 & 11 & Femur & War wound & Vastus lateralis & $\begin{array}{l}\text { Three episodes of discharge } \\
\text { after operation }\end{array}$ & 5 & 2 \\
\hline 12 & 64 & 38 & Femur & War wound & Short head biceps & Primary healing & 5 & 0 \\
\hline 13 & 56 & 36 & Femur & War wound & Direct closure & Primary healing & 5 & 0 \\
\hline 14 & 22 & 3 & Femur & War wound & Vastus lateralis & $\begin{array}{l}\text { Delayed healing. Omitted } \\
\text { caliper; fracture; amputation. } \\
\text { Stump has remained healed }\end{array}$ & 4 & 10 \\
\hline 15 & 30 & 1 & Femur & War wound & Short head biceps & Persistent recurrent discharge & 4 & 9 \\
\hline 16 & 25 & 1 & Femur & $\begin{array}{l}\text { Post-operative } \\
\text { infection }\end{array}$ & Vastus lateralis & $\begin{array}{c}\text { Transitory discharge } \\
\text { six weeks after operation. } \\
\text { Thereafter healed }\end{array}$ & 5 & 8 \\
\hline 17 & 59 & 28 & Femur & War wound & Vastus lateralis & Primary healing & 4 & 8 \\
\hline 18 & 33 & 12 & Femur & War wound & Vastus lateralis & Primary healing & 4 & 7 \\
\hline 19 & 56 & 36 & Femur & War wound & Direct closure & Primary healing & 4 & 4 \\
\hline 20 & 22 & 4 & Femur & War wound & Vastus medialis & $\begin{array}{l}\text { Primary healing. Omitted } \\
\text { caliper; fracture; amputation. } \\
\text { Stump has remained healed }\end{array}$ & 4 & 0 \\
\hline 21 & 33 & 9 & Femur & War wound & Direct closure & $\begin{array}{c}\text { Transitory discharge } \\
\text { shortly after operation. } \\
\text { Thereafter healed }\end{array}$ & 4 & 0 \\
\hline 22 & 42 & 10 & Femur & War wound & Direct closure & Primary healing & 3 & 10 \\
\hline 23 & 28 & 11 & Femur & $\begin{array}{c}\text { Acute } \\
\text { osteomyelitis }\end{array}$ & $\begin{array}{l}\text { Vastus medialis and } \\
\text { short head of biceps }\end{array}$ & $\begin{array}{l}\text { Persistent discharge for } \\
\text { eighteenmonthsafteroperation } \\
\text { terminating in extrusion of } \\
\text { suture. Thereafter healed }\end{array}$ & 3 & 3 \\
\hline
\end{tabular}


TABLE I-continued

\begin{tabular}{|c|c|c|c|c|c|c|c|c|}
\hline $\begin{array}{c}\text { Case } \\
\text { number }\end{array}$ & $\underset{(\text { years })}{\text { Age }}$ & $\begin{array}{l}\text { Duration } \\
\text { of infection } \\
\text { (vears) }\end{array}$ & Site & Origin & Tissue replacement & Result & \multicolumn{2}{|c|}{$\begin{array}{c}\text { Follow-up } \\
\text { yearsmonths }\end{array}$} \\
\hline 24 & 49 & 34 & Femur & $\begin{array}{c}\text { Acute } \\
\text { osteomyelitis }\end{array}$ & $\begin{array}{l}\text { Vastus lateralis and } \\
\text { short head of biceps }\end{array}$ & Delayed primary healing & 2 & 9 \\
\hline 25 & 48 & 23 & Femur & $\begin{array}{l}\text { Acute } \\
\text { osteomyelitis }\end{array}$ & Short head of biceps & Delayed primary healing & 1 & 8 \\
\hline 26 & 25 & 19 & Femur & $\begin{array}{c}\text { Acute } \\
\text { osteomyelitis }\end{array}$ & Direct closure & Primary healing & 1 & 7 \\
\hline 27 & 42 & 10 & Femur & $\begin{array}{c}\text { Acute } \\
\text { osteomyelitis }\end{array}$ & Direct closure & Primary healing & 1 & 6 \\
\hline 28 & 62 & 46 & Femur & $\begin{array}{l}\text { Acute } \\
\text { osteomyelitis }\end{array}$ & Vastus medialis & Primary healing & 1 & 6 \\
\hline 29 & 20 & 2 & Femur & $\begin{array}{c}\text { Secondary } \\
\text { infection } \\
\text { complicating } \\
\text { healed } \\
\text { tuberculosis }\end{array}$ & $\begin{array}{l}\text { Vastus lateralis } \\
\text { and tensor } \\
\text { fasciae latae }\end{array}$ & $\begin{array}{l}\text { Primary healing. } \\
\text { Flare one month after } \\
\text { operation; thereafter healed }\end{array}$ & 1 & 3 \\
\hline 30 & 50 & 42 & Femur & $\begin{array}{l}\text { Acute } \\
\text { osteomyelitis }\end{array}$ & $\begin{array}{l}\text { Vastus lateralis and } \\
\text { short head of biceps }\end{array}$ & $\begin{array}{c}\text { Two subsequent episodes } \\
\text { of inflammation }\end{array}$ & 0 & 6 \\
\hline 31 & 38 & 8 & Tibia & War wound & Rotation flap & Primary healing & 7 & 7 \\
\hline 32 & 28 & 6 & Tibia & War wound & $\begin{array}{l}\text { Rotation flap and } \\
\text { cancellous free } \\
\text { bone grafts }\end{array}$ & $\begin{array}{l}\text { Sequestrectomy } \\
\text { two months later. } \\
\text { Thereafter healed }\end{array}$ & 7 & 6 \\
\hline 33 & 36 & 9 & Tibia & War wound & Rotation flap & Primary healing & 7 & 5 \\
\hline 34 & 56 & 34 & Tibia & War wound & Rotation flap & $\begin{array}{l}\text { Delayed primary healing. } \\
\text { Eczema before and after } \\
\text { operation, now healed }\end{array}$ & 7 & 2 \\
\hline 35 & 38 & 32 & Tibia & $\begin{array}{c}\text { Acute } \\
\text { osteomyelitis }\end{array}$ & $\begin{array}{l}\text { Extensor hallucis } \\
\text { longus and double } \\
\text { pedicle flap }\end{array}$ & Primary healing & 6 & 10 \\
\hline 36 & 58 & 36 & Tibia & War wound & $\begin{array}{l}\text { Soleus and } \\
\text { rotation flaps }\end{array}$ & Primary healing & 6 & 3 \\
\hline 37 & 36 & 9 & Tibia & War wound & Rotation flap & Primary healing & 6 & 1 \\
\hline 38 & 36 & 7 & Tibia & War wound & Rotation flap & Primary healing & 5 & 8 \\
\hline 39 & 34 & 9 & Tibia & War wound & Rotation flap & Primary healing & 5 & 6 \\
\hline 40 & 58 & 36 & Tibia & War wound & Rotation flap & Primary healing & 5 & 3 \\
\hline 41 & 55 & 33 & Tibia & War wound & Rotation flap & $\begin{array}{l}\text { Partial loss of flap; } \\
\text { persistently unstable scar }\end{array}$ & 5 & 0 \\
\hline 42 & 29 & 6 & Tibia & War wound & $\begin{array}{l}\text { Rotation flap and } \\
\text { cancellous free } \\
\text { bone grafts }\end{array}$ & Primary healing & 4 & 9 \\
\hline 43 & 39 & 11 & Tibia & War wound & Rotation flap & $\begin{array}{l}\text { Intermittent persistent } \\
\text { discharge }\end{array}$ & 4 & 0 \\
\hline 44 & 42 & 11 & Tibia & War wound & Rotation flap & Primary healing & 3 & 7 \\
\hline 45 & 42 & 21 & Tibia & $\begin{array}{c}\text { Acute } \\
\text { osteomyelitis }\end{array}$ & $\begin{array}{l}\text { Cross-leg flap, } \\
\text { rotation flap and } \\
\text { double pedicle flap }\end{array}$ & Primary healing & 3 & 6 \\
\hline 46 & 48 & 6 & Tibia & $\begin{array}{l}\text { Pin-track } \\
\text { infection }\end{array}$ & Rotation flap & $\begin{array}{l}\text { Bone chip removed nine } \\
\text { months later, thereafter healed }\end{array}$ & 2 & 3 \\
\hline
\end{tabular}

VOL. 41 B, NO. 4, NOVEMBER 1959 
TABLE I-continued

\begin{tabular}{|c|c|c|c|c|c|c|c|c|}
\hline $\begin{array}{c}\text { Case } \\
\text { number }\end{array}$ & $\underset{(\text { years })}{\text { Age }}$ & $\begin{array}{c}\text { Duration } \\
\text { of infection } \\
(\text { years })\end{array}$ & Site & Origin & Tissue replacement & Result & \multicolumn{2}{|c|}{$\begin{array}{c}\text { Follow-up } \\
\text { yearsmonths }\end{array}$} \\
\hline 47 & 7 & 2 & Tibia & $\begin{array}{c}\text { Acute } \\
\text { osteomyelitis }\end{array}$ & Tibialis anterior & $\begin{array}{l}\text { Two post-operative flares, } \\
\text { one accompanied by } \\
\text { abortive infection in radius }\end{array}$ & 2 & 3 \\
\hline 48 & 53 & 30 & Tibia & War wound & Direct closure & $\begin{array}{l}\text { Two recurrences } \\
\text { after operation }\end{array}$ & 2 & 0 \\
\hline 49 & 33 & 4 & Tibia & $\begin{array}{l}\text { Industrial } \\
\text { accident }\end{array}$ & Cross-leg flap & Primary healing & 1 & 7 \\
\hline 50 & 29 & 18 & Tibia & $\begin{array}{c}\text { Acute } \\
\text { osteomyelitis }\end{array}$ & $\begin{array}{l}\text { Tibialis anterior } \\
\text { and rotation flap }\end{array}$ & Delayed primary healing & 1 & 7 \\
\hline 51 & 54 & 25 & Tibia & $\begin{array}{c}\text { Acute } \\
\text { osteomyelitis }\end{array}$ & Rotation flap & Delayed primary healing & 0 & 6 \\
\hline 52 & 69 & 42 & Tibia & War wound & $\begin{array}{c}\text { Delayed } \\
\text { direct closure }\end{array}$ & Primary healing & 0 & 6 \\
\hline 53 & 66 & 45 & Tibia & $\begin{array}{c}\text { Acute } \\
\text { osteomyelitis }\end{array}$ & Rotation flap & Delayed primary healing & 0 & 3 \\
\hline 54 & 48 & 9 & Talus & War wound & Rotation flap & Primary healing & 6 & 10 \\
\hline 55 & 56 & 36 & $\begin{array}{c}\text { First } \\
\text { metatarsal }\end{array}$ & War wound & Rotation flap & $\begin{array}{c}\text { Transitory discharge } \\
\text { one month after operation. } \\
\text { Thereafter healed }\end{array}$ & 5 & 9 \\
\hline 56 & 54 & 35 & Sacrum & War wound & Erector spinae & $\begin{array}{c}\text { Transitory discharge } \\
\text { two months after operation. } \\
\text { Thereafter healed }\end{array}$ & 5 & 7 \\
\hline 57 & 29 & 10 & Radius & War wound & Direct closure & Primary healing & 4 & 6 \\
\hline 58 & 69 & 3 & Ilium & $\begin{array}{l}\text { Post-operative } \\
\text { infection }\end{array}$ & Gluteus maximus & Delayed primary healing & 1 & 8 \\
\hline
\end{tabular}

\section{TECHNIQUE OF OPERATION}

Only tentative operative plans can be made from the appearances of the sinus and radiographs. The duration of the operation cannot be forecast and blood should be available for transfusion.

Tourniquet-A pneumatic tourniquet is employed whenever feasible. The operation may be lengthy and may be prolonged beyond the period normally considered safe for tourniquet occlusion, but ill effects from the tourniquet have been observed in only one case, in which a pneumatic tourniquet could not be used: necrosis of the skin and muscle flap occurred, but the wound subsequently healed.

The advisability of releasing the tourniquet during the operation has been considered and rejected. Many of these operations are technically difficult and carry an unjustifiably greater risk of injury to vessels and nerves if a bloodless field is not obtained. In three cases a tourniquet could not be used and hypotension was not induced. These operations proved incomparably more difficult and dangerous and shock was undoubtedly increased.*

Incision-The incision first comprises a simple excision of the sinus; it is enlarged as the operation progresses, the probable soft-tissue reconstruction being kept in mind. A simple linear or curvi-linear extension may be made, but, especially in the popliteal fossa or just below the knee, care has to be taken not to devitalise areas that might be required for skin

* When the risk of circulatory deficiency seems especially great the possibility of doing the reconstructive phase of the operation after an interval of two or three days is being considered. 
flaps. Often previous scars dictate incisions which considerably modify the most direct approach.

Excision-The first phase of the operation is an excision of tissues with an inadequate blood supply. All fibrosed soft tissues are excised down to the periosteum, no matter how distant from the sinus or apparently free from infection. This is the longest stage of the operation: dissection is slow and must be careful because fibrosis often grips the great vessels as in a vice. I believe that complete excision is essential; the results show that failure seems to occur when excision has not been meticulous. In order to preserve osseous blood supply the periosteum is excised flush with the subjacent bone and is not stripped from it. The bone cavity is exposed and excision is continued until no sclerosed bone is left and normal blood vessels show on all cut surfaces. Bone involvement is usually found to be more extensive than that of the soft tissues, and further exposure is necessary. This is simple because only normal muscle remains and the planes of natural cleavage can be used.

The vitality of the limb is particularly in danger when the popliteal fossa is involved in scar tissue; but even there the sinus has been cured only when thorough excision has been carried out. Our earlier impression that this was not a practical surgical proposition has been corrected by good results obtained later in the series. Occasionally a large vessel has been previously destroyed, and the vitality of the limb depends on a collateral circulation of unsuspected importance.

The aim of the operation is to remove all scarred tissue, and this is kept clearly in mind when one is excising sclerosed bone. Affected bone can be removed without permanently weakening the limb, even though more than half of the diameter of the shaft may be involved. New bone is formed rapidly if the operation is successful and infection is overcome.

Reconstruction-The second or reconstructive phase of the operation is the filling up of all dead space, using tissue of rich blood supply which will retain its circulation after displacement. A muscle graft is usually available in the thigh, where the short head

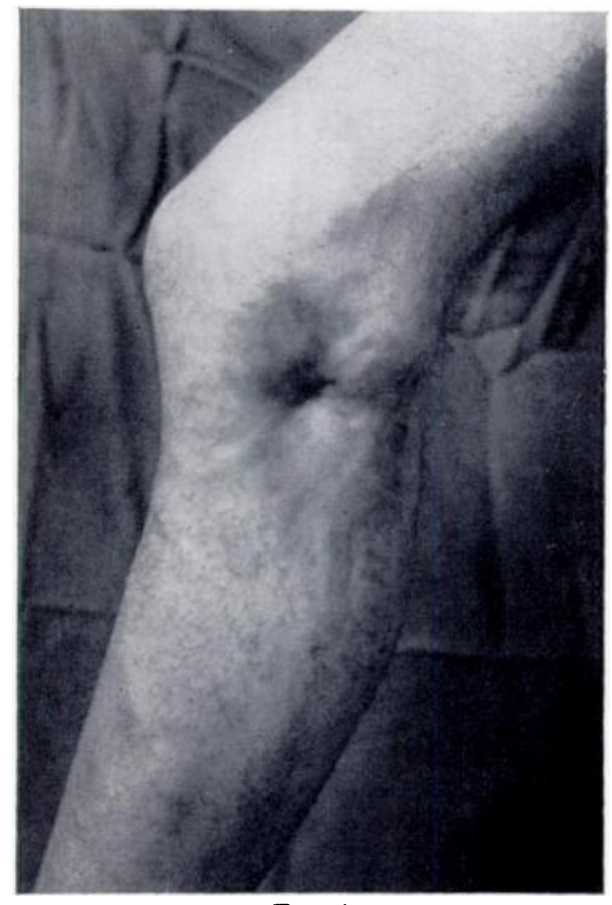

FIG. 1

Typical sinus. This patient has a mobile knee, and muscle grafting will probably be impracticable.

of biceps or the vasti are commonly used. The range of movement of the knee is often already limited, and no qualms are felt then over reduction of muscular efficiency. Sometimes only part of a muscle is required; sometimes two muscles are needed for the dead space to be adequately filled. Care is taken to preserve the blood and nerve supply of the graft and to allow for anatomical anomalies of the hila. When the muscle is introduced into the cavity a ridge of normal bone may have to be taken away to enable the graft to lie comfortably in its new bed. The muscle graft is secured either with removable silk sutures, brought out through the skin, or with rather fine non-chromic catgut. The deep fascia and the skin are closed together by removable double mattress sutures.

In areas where muscle grafting is impracticable, or where the skin is widely scarred, skin flaps are used. Rotation or double pedicle flaps are employed or (at a second stage) cross-leg flaps (Fig. 2). Saucerisation of bone may have to be extensive to avoid tension, and flaps have to be planned with a good safety margin. I consider that to use a temporary free graft over the excised area is inadvisable, but if this has to be done before a cross-leg flap the next stage

VOL. 41 B, No. 4, NOVEMBer 1959 
should be undertaken as soon as possible. Free split-skin grafts had been applied in some patients who came to us after previous operations, and we believed that these wounds may have broken down because the graft had no blood supply of its own and the scar was thin and unstable rather than because infected bone had not been adequately removed. For the same reason cavities are not now filled with cancellous bone chips. The operation site is bound to be grossly contaminated and it is difficult to visualise an organism which has been comfortably commensal in the body for many years being completely destroyed by an antibiotic during the few hours in which the haematoma surrounding bone chips can retain its antibiotic powers; deprived of a free blood supply, the chips can only form a nidus for reinfection.

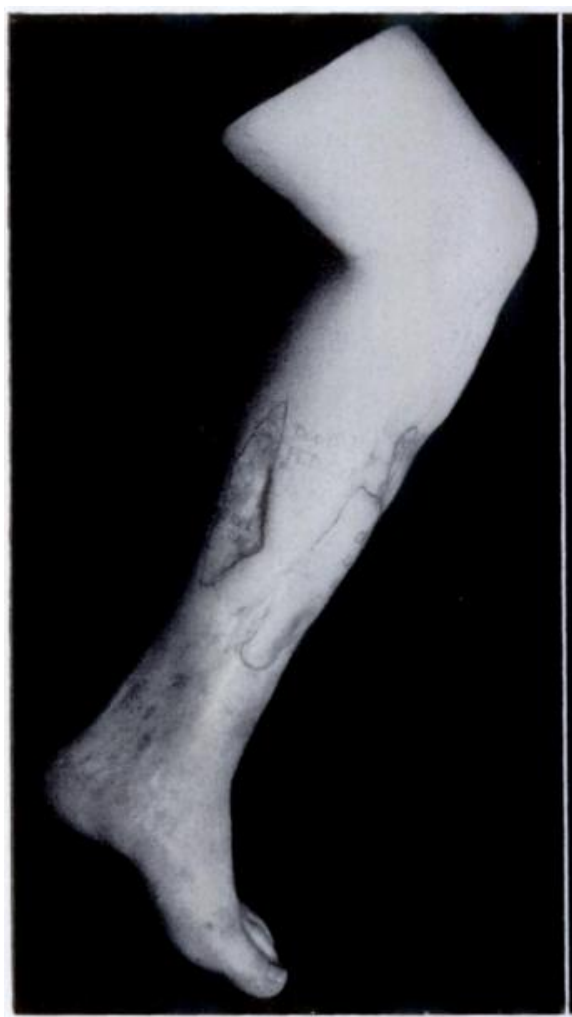

Case 45-Osteomyelitis of tibia. Nearly all the diseased bone

diseased bone had been excised at a previous recent operation but the scar was unstable over almost the whole length of the tibia, and small sequestra were extruded intermittently. Reconstruction was hampered by an arthrodesed hip and recurrent antral infection. The result now appears to be successful; the wound has been healed since the last reconstructive operation over two years ago for the first time in twenty-one years.

Post-operative care-No drain is used. The limb is immobilised and elevated. Antibiotic therapy is continued for about six weeks, even despite apparent primary healing. A cautionary watch is kept on the white cell count because most patients have had previous courses of antibiotic therapy. When a muscle flap has been used, movements are discouraged for the first three weeks. The wounds are not dressed for two weeks, unless odour or purulent discharge indicates infection. Clear serous discharge may penetrate the thickest dressings after extensive muscle grafting, but this is not considered an indication for early dressing in the absence of odour: healing in these cases is usually complete in two weeks. When there has been extensive resection of bone in the leg. a weight-relieving caliper is used until radiographs demonstrate adequate strength. 


\section{COMPLICATIONS}

General complications were surprisingly few, and none was fatal.

Skin defects-Rotation flaps below the knee often result in a slowly healing wound, and in some cases there was loss of part of the flap; this did not always indicate failure to cure the sinus. Full skin cover was obtained as soon as possible by further grafting. If only the superficial part of the full-thickness graft had been lost a permanent free graft could be used. Transitory discharge-Some wounds seem to heal well for the first few weeks, when a transitory and often painless discharge recurred. A fragment of suture material or a bone chip might then be extruded, but sometimes no obvious cause was found. Many of these patients have shown no further recurrence of discharge, but one cannot be certain that infection is cured. Ten patients recorded here showed such a single brief reopening of the sinus, but the results are tentatively regarded as successful.

Pathological fracture-Two patients sustained pathological fractures after operation: their calipers had been removed prematurely, against advice, for a social occasion. In both cases amputation then became inevitable.

Stiffiness in adjacent joints - In general, patients and their doctors have reported no change in the range of movement after operation, but accurate figures cannot be given.

Persistent pain-This has occurred in several cases despite apparent cure of the sinus, and may. in fact. be associated with previously noted joint stiffness rather than an infective process; conversely, operation has sometimes relieved pain though the sinus has recurred.

Amputation-Primary amputation has not been indicated in these cases. Amputation was indicated later in the two patients mentioned above who suffered pathological fractures. We realise that it may be indicated primarily in resistant septicaemia or severe general debility.

TABLE II

Duration of Observation in Forty-eight Patients with Primary Healing and Apparent Cure

\begin{tabular}{|cc|}
\hline Duration of observation & Number of patients \\
\hline Over 7 years & 5 \\
$6-7$ years & 6 \\
$5-6$ years & 14 \\
$4-5$ years & 6 \\
$3-4$ years & 4 \\
$2-3$ years & 2 \\
$1-2$ years & 8 \\
Less than 1 year & 3 \\
\hline
\end{tabular}

\section{RESULTS}

Results in the patients treated in the manner described and operated upon personally are recorded below and in Table I. The follow-up has been either by personal examination or by letters to both the patient and his own doctor. Some of these patients had had temporary relief from discharge after previous less radical operations, and the apparently successful results cannot be regarded as final.

Out of the fifty-eight patients operated upon forty-eight showed primary healing and are now apparently free from infection. The duration of observation in these cases is shown in Table II.

VOL. 41 B, NO. 4, NOVEMBer 1959

C 
There has been a recurrence of infection and probable failure in ten patients. These include the two patients with pathological fracture (Cases 14 and 20), though one had shown primary healing. Incomplete removal of fibrous tissue from the popliteal fossa probably accounted for failure in Case 11. This patient's last "abscess" was sterile and occurred two years ago: his natural resistance may yet overcome the infection. In Case 30 inflammation has been slight and confined to the soft tissues, and the wound is now healed for the first time in forty-two years.

In Case 41 the wound would probably have healed with cleanliness and protection. Final follow-up has been impossible owing to the patient's mental illness. In Case 43 the rotation flap was inadequate, and a cross-leg flap would have been a wiser procedure.

General debility aided recurrence in Cases 47 and 48, and the improvement in home conditions in the case of the child has been followed by apparently sound healing of the leg, ultimate success being probable.

I wish to express my thanks to Mr G. Hyman, Mr R. I. Stirling and Mr W. I. Paterson for their encouragement and for their generosity in allowing me to operate upon their patients.

\section{REFERENCES}

BAUR, E. (1957): Behandlungsergebnisse traumatischer Osteomyelitiden der unteren Extremitäten. Zeitschrift für Unfallmedizin and Berufskrankheiten, 50, 40.

Blair, J. E. (1948): Comments on the Laboratory Aspects of Penicillin Therapy. Bulletin of the Hospital for Joint Diseases, 9, 182.

Brash, J. C. (1955): Neuro-Vascular Hila of Limb Muscles. Edinburgh: E. \& S. Livingstone Ltd.

Buchman, J. (1948): The Rationale of the Treatment of Chronic Osteomyelitis. Bulletin of the Hospital for Joint Diseases, 9, 177.

Buchman, J., and Blair, J. E. (1945): Penicillin in the Treatment of Chronic Osteomyelitis. Archives of Surgery, 51, 81.

ENDLER, F. (1957): Die medikamentöse Lokalbehandlung der Osteomyelitis und ihre Ergebnisse. Wiener Medizinische Wochenschrift, 107, 653, 689.

ENDLER, F. (1957): Klinische und experimentelle Untersuchungen zur Frage der Osteomyelitis. Klinische Medizin, 12, 388.

Kelly, R. P. (1946): Skin-Grafting in the Treatment of Osteomyelitic War Wounds. Journal of Bone and Joint Surgery, 28, 681.

KNIGHT, M. P., and Wood, G. O. (1945): Surgical Obliteration of Bone Cavities Following Traumatic Osteomyelitis. Journal of Bone and Joint Surgery, 27, 547.

Leahey, E. B. (1952): Primary Closure in Chronic (Nontuberculous) Osteomyelitis. New York State Journal of Medicine, 52, 1,045 .

Stirling, R. I. (1950): In Operative Surgery. Edited by A. Miles and Sir J. Learmonth. London: Geoffrey Cumberlege, Oxford University Press. 